\title{
PENGARUH KEDISIPLINAN DAN TASK COMMITMENT TERHADAP PRESTASI BELAJAR MATEMATIKA
}

\author{
Anies Pianyta \\ PB Soedirman International Islamic Junior High School \\ Jln. Raya Bogor KM.24, Cijantung, Jakarta Timur. \\ e-mail: pianytanies@ymail.com
}

\begin{abstract}
Abstrak: Pengaruh Kedisiplinan dan Task Commitment terhadap Prestasi Belajar Matematika. Penelitian survei korelasional regresi ganda ini bertujuan untuk: (1) Mengetahui pengaruh kedisiplinan dan task commitment secara bersama-sama terhadap prestasi belajar matematika; (2) Mengetahui pengaruh kedisiplinan terhadap prestasi belajar matematika; dan (3) Mengetahui pengaruh task commitment terhadap prestasi belajar matematika. Manfaat penelitian ini adalah untuk menambah khasanah keilmuan dalam upaya meningkatkan kualitas mutu pendidikan nasional. Penelitian dilaksanakan di SMP PGRI Plumbon, Kabupaten Cirebon, pada tahun pelajaran 2015/2016 dengan teknik pengambilan sampel adalah simple random sampling, dimana banyaknya sampel adalah 56 responden yang diambil dari populasi terjangkau berjumlah 65 responden. Instrumen yang digunakan berupa tes untuk prestasi belajar matematika serta berupa angket untuk kedisiplinan dan task commitment, dimana semua instrumen untuk masing-masing variabel sudah divalidasi secara empirik. Pengujian hipotesis dilakukan setelah data memenuhi uji asumsi klasik berupa uji normalitas, uji linearitas, dan uji multikolinearitas. Pengujian hipotesis penelitian dengan uji $\boldsymbol{F}$ dan uji $\boldsymbol{t}$. Hasil penelitian menunjukkan: (1) Terdapat pengaruh yang signifikan kedisiplinan dan task commitment secara bersamasama terhadap prestasi belajar matematika, yaitu sebesar 37,3\%; (2) Terdapat pengaruh yang signifikan kedisiplinan terhadap prestasi belajar matematika, yaitu sebesar 20,8\%; (3) Terdapat pengaruh yang signifikan task commitment terhadap prestasi belajar matematika, yaitu sebesar $16,5 \%$.
\end{abstract}

\section{Kata Kunci: Kedisiplinan, Task Commitment, Prestasi Belajar Matematika.}

\begin{abstract}
The impacts of discipline and task commitment on mathematical learning achievement. This corrasional survey research with double regression analysis is aimed at 1) acknowledging the impacts of both discipline and task commitment on mathematical learning achievement all together 2) acknowledging the impacts of discipline on mathematical learning achievement 3) acknowledging the impact of task commitment on mathematical learning achievement. The benefits of this research is to add knowledge and increase the quality of national education. This research was conducted at SMP PGRI Plumbon, Cirebon District in 2015/2016 by using simple random sampling with 56 respondents taken from the number of affordable population reach as many as 65 respondents. The instrument used is test on variables of mathematical learning achievement and questionnaire on variables of discipline and task commitment and all instruments have been empirically validated. Hypothesis is conducted after the data fulfill in series of classic assumption test, i.e. normality test, linearity test and multicollinearity test. Hypothesis test with $F_{\text {test }}$ and $\boldsymbol{t}_{\text {test }}$. The research result show that 1) there are significant impacts of both discipline and task commitment on mathematical learning achievement all together about 37,3\% 2) there are significant impacts of disciple on mathematical learning achievement about $20,8 \%$; 3) there are significant impacts of task commitment on mathematical learning achievement about $16,5 \%$.
\end{abstract}

Keywords: Discipline, Task Commitment, Mathematical Learning Achievement. 


\section{PENDAHULUAN}

Pendidikan merupakan salah satu hal penting dalam kehidupan berbangsa dan bernegara. Kontribusi pendidikan bagi negara sangat besar dalam meningkatkan kualitas sumber daya manusia di masa mendatang. Sumber daya manusia yang mampu bersaing dan berkualitas tinggi merupakan salah satu faktor penentu dalam peningkatan segala aspek kehidupan berbangsa dan bernegara. Melihat begitu pentingnya pendidikan, menjadikan pendidikan sebagai hal yang wajib dilaksanakan secara berkesinambungan guna menjawab segala tantangan dan perubahan zaman. Berpijak pada kebutuhan di masa mendatang, diperlukan perhatian seksama yang fokus dan serius dalam penyelenggaraan pendidikan.

Menciptakan pendidikan yang berkualitas yaitu pendidikan dengan sumber daya manusia yang berkualitas, tidak hanya mengandalkan pemerintah, melainkan dibutuhkan dukungan dari berbagai pihak. Dalam hal ini adalah siswa dan guru sebagai subjek pendidikan dan masyarakat sebagai faktor pendukung terbesar. Akan tetapi, masih ditemukan masing-masing faktor tidak berjalan sebagaimana semestinya. Siswa sebagai subjek pendidikan merupakan individu yang kompleks. Dikatakan kompleks karena setiap individu tidaklah sama, setiap individu mempunyai sifat, watak, perilaku maupun karakter yang berbeda-beda. Dalam suatu proses perkembangan, banyak hal yang dapat memengaruhi maupun dapat merubah karakter setiap individu. Bukan hanya proses perkembangan individu mudah terpengaruh oleh hal-hal dari luar, akan tetapi juga dalam proses belajar.

Beberapa kendala lain yang cukup besar pengaruhnya, secara khusus di kalangan pelajar antara lain masih rendahnya sikap disiplin, kurangnya motivasi, serta kurangnya minat belajar. Kendala-kendala inilah yang menjadi batu sandungan bagi sumber daya manusia usia muda yang kelak akan mencerminkan jati diri suatu bangsa. Beberapa guru dan ahli psikologi telah mencoba mengidentifikasi masalahmasalah yang ada di dalam kelas, salah satunya adalah komitmen terhadap tugas yang rendah, inisiatif dan keterlibatan yang rendah, motivasi pribadi, yang dapat dinyatakan dalam kurangnya keterlibatan berpartisipasi dalam pekerjaan-pekerjaan di dalam kelas (Djiwandono, 2002: 321).

Kesulitan yang dialami siswa biasanya pada mata pelajaran matematika. Matematika bagi sebagian siswa dianggap pelajaran yang sukar dan biasanya belajar matematika memerlukan kosentrasi tinggi. Saat ini masih banyak siswa yang mengalami kesulitan belajar matematika. Mereka menganggap matematika suatu mata pelajaran yang membosankan, menakutkan, menjadi beban bagi siswa karena bersifat abstrak, penuh dengan angka dan rumus. Selain itu, masih adanya sistem belajar yang menyamakan kemampuan siswa, kurangnya motivasi dari guru, sikap guru di dalam kelas, dan metode pengajaran yang monoton. Saat siswa belum menguasai materi dasar, sudah ditambah dengan materi lain. Siswa pun cenderung tidak menyukai matematika karena dianggap sulit terutama dalam menyelesaikan soal-soal yang diberikan oleh guru matematika. Dari berbagai kesulitan yang dialami siswa tersebut telah banyak upaya yang dilakukan oleh pemerintah mulai dari memberlakukan kurikulum 2013 yang dinilai layak, uji kompetensi guru, dan peningkatan kesejahteraan guru untuk memberikan semangat pada guru-guru agar lebih meningkatkan kinerjanya. 
Dalam realita di lapangan, berdasarkan hasil observasi bahwa matematika menjadi pelajaran yang susah bagi siswa. Hal tersebut terlihat dari prestasi belajar matematika siswa kelas VIII di SMP PGRI Plumbon Kabupaten Cirebon yang masih di bawah KKM (Kriteria Ketuntasan Minimal). Kemudian, dipertegas dengan penuturan dari guru mata pelajaran matematika di SMP PGRI Plumbon Kabupaten Cirebon bahwa rendahnya prestasi belajar tersebut disebabkan karena kurangnya kedisiplinan siswa terutama dalam hal penugasan yang telah diberikan guru. Sebagian besar siswa menunda-nunda untuk menyelesaikan tugasnya dan lebih parahnya lagi siswa tidak mengerjakan tugasnya di rumah, melainkan di sekolah sebelum pelajaran dimulai.

Setiap orang memiliki sikap disiplin dalam dirinya masing-masing, namun sayang kebanyakan mereka tidak melatih, menerapkan dan membiasakan sikap disiplin itu sendiri dalam kehidupan sehari-hari. Sebenarnya, setiap orang memiliki tingkat kedisiplinan yang tinggi yang sering kali siswa tidak menyadari atau lebih tepatnya tidak membiasakan menerapkan sikap disiplin dalam diri mereka. Pentingnya sikap disiplin dalam diri seseorang agar seorang dapat lebih mengarahkan dirinya sendiri tanpa pengaruh dan pengendalian dari orang lain. Ketika mereka mulai melatih, menerapkan dan membiasakan dalam dirinya untuk mulai bersikap disiplin, hal apapun yang mereka lakukan dan mereka kerjakan akan lebih bermanfaat sehingga dapat memeroleh hasil yang baik.

Banyak yang beranggapan bahwa untuk memiliki sikap disiplin, seseorang perlu energi ekstra atau energi yang banyak agar dapat mengendalikan diri mereka. Supaya mereka terhindar dari sikap malas dan menganggap mudah semua hal. Sesungguhnya sebagaimana disebutkan bahwa setiap orang perlu bahkan harus bisa melatih, menerapkan dan membiasakan sikap disiplin dalam diri mereka secara bertahap. Sehingga dalam keadaan seperti apapun, kapanpun dan dimanapun mereka akan terbiasa bersikap disiplin.

Sikap disiplin sangat erat kaitannya dengan proses belajar mengajar, khususnya pada pelajaran matematika. Keberhasilan seseorang dipengaruhi oleh banyak faktor, secara garis besar faktor tersebut dapat dibedakan menjadi dua yaitu faktor dari dalam diri siswa dan dari luar siswa itu sendiri. Faktor dari dalam diri siswa adalah faktor yang sangat penting untuk menentukan keberhasilan belajar siswa. Hal tersebut dapat dipahami sebab dalam proses belajar sasarannya adalah individu sebagai objek belajar. Slameto (2010: 2) mengatakan bahwa "belajar adalah suatu proses usaha yang dilakukan oleh seseorang untuk memperoleh suatu perubahan tingkah laku yang baru secara keseluruhan, sebagai hasil pengalamannya sendiri dalam interaksi dengan lingkungannya".

Keberhasilan juga dapat diciptakan melalui kedisiplinan siswa dalam belajar. Siswa yang belajar akan lebih mudah dalam menguasai pengetahuan yang diberikan dan dapat dimanfaatkan dalam kehidupan di masyarakat. Kedisiplinan belajar dapat ditingkatkan melalui pembelajaran matematika. Karena dalam pembelajaran matematika dibutuhkan kedisiplinan yang tinggi. Oleh karena kekhasan matematika tersebut, maka belajar matematika harus dilakukan secara runtut dan kontinu agar dicapai hasil belajar yang maksimal.

Siswa yang berhasil untuk belajarnya dalam artian memiliki tingkat intelektual yang jauh di atas 
rata-rata anak seusianya sering dianggap sebagai anak berbakat. Namun, definisi tentang keberbakatan, Renzulli (dalam Akbar,, 2005: 71) mengemukakan bahwa, "perilaku berbakat terdiri dari perilaku yang mencerminkan adanya interaksi dari ketiga cluster ciri dasar manusia yang meliputi: kemampuan umum dan atau spesifik, tingkat tanggung jawab terhadap tugas (task commitment) yang tinggi dan tingkat kreativitas yang tinggi". Anak berbakat adalah mereka yang mempunyai ketiga ciri dan menampilkannya sebagai potensi yang dimiliki ke segala bidang. Adapun task commitment (tanggung jawab terhadap tugas) berperan mendorong seseorang untuk tekun dan ulet, meskipun mengalami berbagai rintangan karena orang tersebut telah mengikatkan diri pada tugas atas kehendaknya sendiri. Dengan adanya task commitment, seseorang diharapkan dapat meningkatkan prestasi belajarnya.

Menurut Arikunto (2006: 53), "prestasi belajar mencerminkan sejauh mana siswa telah dapat mencapai tujuan yang telah ditetapkan di setiap bidang studi". Belajar itu sendiri merupakan suatu proses dari seseorang yang berusaha untuk memeroleh suatu bentuk perubahan perilaku yang relatif menetap. Dalam kegiatan belajar yang terprogram yang disebut proses pembelajaran dan tujuan pembelajaran telah ditetapkan oleh guru. Anak yang berhasil dalam belajar adalah yang dapat mencapai tujuan pembelajaran. Banyak penelitian yang berkaitan dengan kedisiplinan dan task commitment dalam pembelajaran matematika, seperti penelitian Supardi, (2014) dan penelitian Firmanto (2013). Kedua penelitian tersebut menunjukkan bahwa ada pengaruh yang signifikan antara kedisiplinan dan task commitment terhadap prestasi belajar matematika.
Permasalahan yang dihadapi siswa mengenai rendahnya prestasi belajar matematika disebabkan oleh rendahnya kedisiplinan dan task commitment. Untuk mengetahui kebenaran anggapan tersebut, menurut peneliti perlu adanya penelitian yang membahas tentang kedisiplinan dan task commitment terhadap prestasi belajar matematika. Uraian di atas, mendorong peneliti untuk melakukan penelitian dengan judul, "Pengaruh Kedisiplinan dan Task Commitment terhadap Prestasi Belajar Matematika"

\section{METODE}

Penelitian ini dilaksanakan pada siswa kelas VIII di SMP PGRI Plumbon Kabupaten Cirebon. Sekolah ini secara tepat beralamat di Jln. Pangeran Antasari No.135, Desa Purbawinangun, Kecamatan Plumbon, Kabupaten Cirebon. Penelitian yang dilaksanakan pada bulan Maret s.d. Mei di tahun 2016 ini merupakan penelitian survei korelasional dengan analisis regresi ganda. Adapun desain penelitian ini digambarkan sebagai berikut:

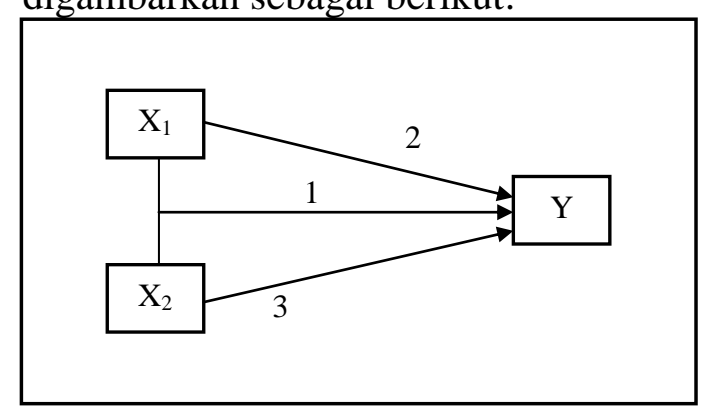

Gambar 1. Desain Penelitian

Keterangan:

$\mathrm{X}_{1}$ : Kedisiplinan

$\mathrm{X}_{2}$ : Task Commitment

$\mathrm{Y}$ : Prestasi Belajar Matematika

1 : Pengaruh Kedisiplinan dan Task Commitment Secara Bersamasama terhadap Prestasi Belajar Matematika 
2 : Pengaruh Kedisiplinan terhadap Prestasi Belajar Matematika

3 : Pengaruh Task Commitment terhadap Prestasi Belajar Matematika

Populasi target dari penelitian ini adalah seluruh siswa di SMP PGRI Plumbon Cirebon pada tahun ajaran 2015/2016. Adapun Populasi terjangkau dari penelitian ini adalah seluruh siswa kelas VIII di SMP PGRI Plumbon Cirebon yang berjumlah 65 orang siswa, dimana 21 siswa ada di kelas VIII.A, 21 siswa ada di kelas VIII.B dan 23 siswa ada di kelas VIII.C. Seluruh siswa kelas VIII dari tiga kelas paralel tersebut, dipilih secara acak berupa undian untuk dijadikan sampel pada penelitian ini. Setelah pengundian, sampel yang digunakan dalam penelitian ini adalah 56 orang siswa yang mana teknik menentukan jumlah sampel dengan menggunakan rumus Taro Yamane (Riduwan, 2006: 65).

Perangkat instrumen pada penelitian ini terdiri dari instrumen bentuk tes dan nontes. Instrumen tes digunakan untuk variabel prestasi belajar matematika. Instrumen nontes digunakan untuk variabel kedisiplinan dan task commitment. Instrumen penelitian divalidasi secara validitas isi dan konstruk maupun divalidasi secara empiris. Validitas isi untuk instrumen dilakukan dengan analisis isi oleh tiga orang pakar. Kemudian untuk validitas empirisnya, instrumen diujicobakan ke 30 orang siswa yang tidak masuk dalam sampel penelitian.

Pengembangan instrumen prestasi belajar matematika berupa instrumen tes tulis dalam bentuk pilihan ganda yang terdiri dari 22 butir soal bentuk multiple choise dengan 4 alternatif pilihan jawaban. Perangkat instrumen tersebut semuanya masuk dalam standar kompetensi: "Menentukan Unsur,
Bagian Lingkaran serta Ukurannya" dan terbangun atas kompetensi dasar: "Menentukan Unsur dan Bagian-bagian Lingkaran, Menghitung Keliling dan Luas Lingkaran, Menggunakan Hubungan Sudut Pusat, Panjang Busur, Luas Juring dalam Pemecahan Masalah". Sebanyak 25 butir soal yang disiapkan, hanya 22 butir soal yang digunakan sebagai sumber pengambilan data untuk hasil belajar matematika peserta didik. Adapun karakteristik instrumen dan hasil ujicoba adalah: instrumen disusun untuk ranah kognitif $\mathrm{C} 1, \mathrm{C} 2$, dan $\mathrm{C} 3$; koefisien tingkat kesukaran instrumen dalam rentang 0,300 s.d. 0,967 meliputi soal-soal dengan kategori mudah, sedang, dan sukar; koefisien daya beda instrumen dalam rentang 0,001 s.d. 0,431 meliputi daya beda soal yang jelek, sedang, dan baik; koefisien validitas dalam rentang 0,341 s.d. 0,718 meliputi tingkat validitas sedang, tinggi, dan sangat tinggi; dan reliabilitas instrumen masuk kategori sangat tinggi dengan skor 0,931 .

Pengembangan instrumen kedisiplinan berupa angket yang mana semua butir pernyataannya masuk dalam aspek kedisiplinan yang disampaikan oleh Prijodarminto yaitu tiga aspek disiplin antara lain: (1) Sikap Mental Disiplin; (2) Sikap Pemahaman Disiplin; dan (3) Sikap Perilaku Disiplin”. Sebanyak 32 butir soal yang disiapkan, semuanya valid dan digunakan sebagai sumber pengambilan data untuk kedisiplinan siswa. Adapun karakteristik instrumen dan hasil ujicoba adalah: koefisien validitas dalam rentang 0,341 s.d. 0,718 meliputi tingkat validitas sedang, tinggi, dan sangat tinggi; koefisien reliabilitas instrumen masuk kategori sangat tinggi dengan skor 0,931. Instrumen komitmen terhadap tugas (task commitment) berupa angket yang mana semua butir 
pernyataannya masuk dalam aspek kedisiplinan yang disampaikan oleh Renzulli yaitu beberapa aspek yang terdapat pada komitmen terhadap tugas (task commitment), antara lain: (1) Mengidentifikasi Masalah; Menentukan Pilihan; dan

Menentukan Standar. Sebanyak 40 buti soal yang disiapkan, ada 37 butir pernyataan yang digunakan sebagai sumber pengambilan data untuk kedisiplinan siswa. Adapun karakteristik instrumen dan hasil ujicoba adalah: koefisien validitas dalam rentang 0,341 s.d. 0,718 meliputi tingkat validitas sedang, tinggi, dan sangat tinggi; koefisien reliabilitas instrumen masuk kategori sangat tinggi dengan skor 0,931 .

Teknik analisis terhadap data hasil penelitian yang dalam hal ini berupa nilai prestasi belajar matematika serta perolehan total skor atas angket kedisiplinan dan angket task commitment dilakukan secara deskriptif dan inferensial. Secara deskriptif, data hasil penelitian dianalisis untuk skor mean, median, dan modus. Adapun maksud analisis skor mean, median, dan modus adalah untuk mendeskripsikan perolehan ukuran pemusatan data dari siswa yang menjadi subjek penelitian. Secara inferensial, data hasil penelitian dianalisis menggunakan uji $\boldsymbol{F}$ dan uji $\boldsymbol{t}$, dengan terlebih dahulu diuji untuk persyaratan analisisnya yaitu uji normalitas, uji linearitas, dan uji multikolinearitas. Uji $\boldsymbol{F}$ dilakukan untuk menguji pengaruh simultan dari dua variabel bebas terhadap variabel terikat. Uji $\boldsymbol{t}$ dilakukan untuk menguji pengaruh parsial dari masing-masing variabel bebas terhadap variabel terikat. Kemudian, teknis perhitungan data hasil penelitian secara keseluruhan dilakukan dengan menggunakan bantuan software Ms. Excel.

\section{HASIL DAN PEMBAHASAN}

\section{Hasil Penelitian}

Jumlah sampel dalam penelitian sebagaimana telah dikemukakan yaitu sebanyak 56 siswa dengan jumlah responden laki-laki sebanyak 32 siswa dan perempuan 24 siswa. Karakteristik responden dalam penelitian ini heterogen berdasarkan aspek kognitifnya, dimana siswa yang menjadi responden secara tingkatan kognitifnya ada kelompok atas, kelompok sedang, dan kelompok rendah. Adapun pengelompokkan tinggi, sedang, dan rendah ini berdasarkan pada hasil belajar matematika yang diraih di setiap akhir pembelajaran, berupa tes ulangan harian atau tes ujian tengah semester, dan tes ujian akhir semester. Kemudian, karakteristik responden dalam penelitian ini juga ditinjau berdasarkan aspek psikologis. Responden berada di fase remaja, fase dimana seorang remaja mengalami perkembangan emosinya. Fase ini terjadi perkembangan emosi yang tinggi, perkembangan kemampuan untuk memahami orang lain, dan menjalin persahabatan. Remaja juga sudah mampu berperilaku yang tidak hanya mengejar kepuasan fisik saja, tetapi meningkat pada psikologis.

Secara deskriptif, pada penelitian ini yang menjadi variabel terikat (Y) adalah prestasi belajar matematika. Data prestasi belajar matematika diperoleh dari perangkat soal tes untuk bab lingkaran sebanyak 22 butir soal. Yang menjadi variabel bebas $\left(\mathrm{X}_{1}\right)$ adalah kedisiplinan. Kedisiplinan diperoleh dari penyebaran angket sebanyak 32 butir pernyataan. Yang menjadi variabel bebas $\left(\mathrm{X}_{2}\right)$ adalah task commitment. Data task commitment diperoleh dari penyebaran angket sebanyak 37 butir pernyataan. Adapun ringkasan hasil penelitian ditampilkan pada tabel 1 . 
Tabel 1. Ringkasan Hasil Perhitungan Statistik Deskriptif

\begin{tabular}{cccc}
\hline Data Statistik & $\begin{array}{c}\text { Prestasi Belajar } \\
\text { Matematika }\end{array}$ & Kedisiplinan & $\begin{array}{c}\text { Task } \\
\text { Commitment }\end{array}$ \\
\hline Nilai Terendah & 9 & 65 & 82 \\
Nilai Tertinggi & 91 & 154 & 179 \\
Mean & 47,04 & 119,12 & 131,26 \\
Median & 41 & 123 & 131 \\
Modus & 18 & 116 & 131 \\
Varians & 560,94 & 521,92 & 692,70 \\
Standar Deviasi & 23,68 & 22,84 & 26,32 \\
Simpangan Baku & 3,16 & 3,06 & 3,52 \\
\hline
\end{tabular}

Sumber: Data primer yang diolah

Secara inferensial, data hasil penelitian diuji untuk asumsi klasiknya yaitu uji normalitas, uji linearitas, dan uji multikolinearitas. Uji normalitas dilakukan untuk mengetahui apakah distribusi data untuk setiap kelompok sampel yang diteliti normal atau tidak. Perhitungan uji normalitas dilakukan dengan uji Chi Square yang perhitungan secara teknisnya menggunakan bantuan software Ms. Excel. Adapun kriteria pengujian normalitas adalah jika $\chi_{\text {hitung }}^{2}<\chi_{\text {tabel }}^{2}$, maka distribusi data dinyatakan normal dan sebaliknya jika $\chi_{\text {hitung }}^{2}>\chi_{\text {tabel }}^{2}$, maka distribusi data dinyatakan tidak normal. Berdasarkan tabel 2 di bawah ini, terlihat bahwa seluruh kelompok sampel yang diteliti memiliki $\chi_{\text {hitung }}^{2}<\chi_{\text {tabel }}^{2}, \quad$ sehingga dapat disimpulkan bahwa seluruh kelompok sampel dalam penelitian ini datanya berdistribusi normal.

Tabel 2. Ringkasan Hasil Perhitungan Uji Normalitas Data

\begin{tabular}{lcccc}
\hline \multicolumn{1}{c}{ Kelompok Data } & Jumlah & \multirow{2}{*}{$\chi_{\text {hitung }}^{2}$} & $\chi_{\text {tabel }}^{2}$ & Simpulan \\
\hline Prestasi Belajar Matematika & 56 & 11,678 & 12,592 & Berdistribusi Normal \\
Kedisiplinan & 56 & 6,253 & 12,592 & Berdistribusi Normal \\
Task Commitment & 56 & 9,638 & 12,592 & Berdistribusi Normal \\
\hline
\end{tabular}

Sumber: Data primer yang diolah

Uji asumsi klasik yang berikutnya adalah uji linearitas. Pengujian linearitas dimaksudkan untuk mengetahui apakah dua variabel berpola linear antara satu sama lainnya. Dengan kata lain, uji linearitas dilakukan dalam rangka menguji model persamaan suatu variabel terikat atas suatu variabel bebas. Kriteria pengujiannya adalah jika $\mathrm{F}_{\text {hitung }}<\mathrm{F}_{\text {tabel }}$, maka kedua variabel berpola linear dan sebaliknya jika $F_{\text {hitung }}$ $>\mathrm{F}_{\text {tabel}}$, maka kedua variabel berpola tidak linear. Oleh karena pada penelitian ini terdapat satu variabel terikat $(\mathrm{Y})$ dan dua variabel bebas $\left(\mathrm{X}_{1}\right.$ dan $\left.\mathrm{X}_{2}\right)$, maka ada dua uji linearitas, yaitu uji linearitas $\mathrm{X}_{1}$ terhadap $\mathrm{Y}$ dan uji linearitas $\mathrm{X}_{2}$ terhadap Y.

Ringkasan hasil perhitungan uji linearitas $\mathrm{X}_{1}$ terhadap $\mathrm{Y}$ diperoleh $\mathrm{F}_{\text {hitung }}$ $=1,134$ dan $F_{\text {tabel }}=1,897$. Simpulan: karena $F_{\text {hitung }}<\mathrm{F}_{\text {tabel }}$, maka kedua variabel berpola linear. Atau dengan kata lain, data hasil penelitian untuk variabel kedisiplinan dan prestasi belajar matematika berpola linear. 
Kemudian ringkasan hasil perhitungan uji linearitas $\mathrm{X}_{2}$ terhadap $\mathrm{Y}$ diperoleh $\mathrm{F}_{\text {hitung }}=1,214$ dan $\mathrm{F}_{\text {tabel }}=1,887$. Simpulan: karena $F_{\text {hitung }}<\mathrm{F}_{\text {tabel }}$, maka kedua variabel berpola linear. Atau dengan kata lain, data hasil penelitian untuk variabel task commitment dan prestasi belajar matematika berpola linear.

Uji asumsi klasik yang terakhir yaitu uji multikolinearitas. Pengujian multikolinearitas dimaksudkan untuk mengetahui hubungan antar variabel bebas, yaitu menguji ada atau tidaknya masalah multikolinearitas antara $\mathrm{X}_{1}$ dan $\mathrm{X}_{2}$. Kriteria pengujian multikolinearitas yaitu jika nilai Variance Inflation Factor $<10$, maka kedua variabel bebas tidak terdapat masalah multikolinearitas. Ringkasan hasil perhitungan uji multikolinearitas diperoleh nilai Variance Inflation Factor $=1,828$. Dengan demikian dapat disimpulkan dalam model regresi tidak terdapat masalah multikoliniearitas antara kedisiplinan $\left(\mathrm{X}_{1}\right)$ dan task commitment $\left(\mathrm{X}_{2}\right)$.

Setelah data hasil penelitian memenuhi seluruh rangkaian uji asumsi klasik, selanjutnya data hasil penelitian diuji hipotesisnya. Adapun uji hipotesis penelitian dilakukan dengan dua cara, yang pertama yaitu dengan uji $\boldsymbol{F}$ untuk membuktikan pengaruh kedisiplinan dan task commitment secara bersamasama terhadap prestasi belajar matematika. Kemudian cara kedua yaitu dengan uji $\boldsymbol{t}$ untuk membuktikan pengaruh kedisiplinan terhadap prestasi belajar matematika dan membuktikan pengaruh task commitment terhadap prestasi belajar matematika. Berikut ini ringkasan hasil pengujian hipotesis penelitian.

1. Hipotesis Pertama yaitu Terdapat Pengaruh Kedisiplinan dan Task Commitment Secara Bersama-sama terhadap Prestasi Belajar Matematika
Hipotesis tersebut diuji menggunakan uji $\boldsymbol{F}$ dengan kriteria pengujian: terima $\mathrm{H}_{0}$ jika $\mathrm{F}_{\text {hitung }}<$ $\mathrm{F}_{\text {tabel }}$, dan tolak $\mathrm{H}_{0}$ jika $\mathrm{F}_{\text {hitung }}>\mathrm{F}_{\text {tabel }}$. Untuk nilai $\mathrm{F}_{\text {tabel }}$ ditentukan dari tabel distribusi $F$ untuk $\alpha=0,05$ serta $d k_{\text {pembilang }}=2$ dan $d k_{\text {penyebut }}=$ 53, besarnya nilai $F_{\text {tabel }}=3,172$. Setelah dilakukan perhitungan pada data hasil penelitian, diperoleh nilai $\mathrm{F}_{\text {hitung }}=15,750$.

Dengan demikian ternyata $\mathrm{F}_{\text {hitung }}>\mathrm{F}_{\text {tabel }}$ atau 15,750 $>3,172$ maka tolak $\mathrm{H}_{0}$ dan terima $\mathrm{H}_{1}$, hal ini dapat diartikan bahwa terdapat pengaruh yang signifikan kedisiplinan $\left(\mathrm{X}_{1}\right)$ dan task commitment $\left(\mathrm{X}_{2}\right)$ secara bersamasama terhadap prestasi belajar matematika (Y). Persamaan regresi gandanya adalah $\widehat{\boldsymbol{Y}}=-33,675+$ $0,379 \boldsymbol{X}_{\mathbf{1}}+0,271 \boldsymbol{X}_{\mathbf{2}}$ dan besarnya kontribusi pengaruh yang signifikan kedisiplinan dan task commitment secara bersama-sama terhadap prestasi belajar adalah $37,3 \%$.

2. Hipotesis Kedua yaitu Terdapat Pengaruh Kedisiplinan terhadap Prestasi Belajar Matematika

Hipotesis tersebut diuji menggunakan uji $\boldsymbol{t}$ dengan kriteria pengujian: terima $\mathrm{H}_{0}$ jika $\boldsymbol{t}_{\text {hitung }}<$ $\boldsymbol{t}_{\text {tabel }}$, dan tolak $\mathrm{H}_{0}$ jika $\boldsymbol{t}_{\text {hitung }}>\boldsymbol{t}_{\text {tabel }}$. Untuk nilai $\boldsymbol{t}_{\text {tabel }}$ ditentukan dari tabel distribusi $\boldsymbol{t}$ untuk $\alpha=0,05$ pada $d k$ $=53$, besarnya nilai $\boldsymbol{t}_{\text {tabel }}=2,006$. Setelah dilakukan perhitungan pada data hasil penelitian, diperoleh nilai $\boldsymbol{t}_{\text {hitung }}=2,477$. Dengan demikian, ternyata $\boldsymbol{t}_{\text {hitung }}>\boldsymbol{t}_{\text {tabel }}$ yaitu 2,477 $>$ 2,006, maka $\mathrm{H}_{0}$ ditolak dan terima $\mathrm{H}_{1}$, hal ini dapat diartikan terdapat pengaruh yang signifikan kedisiplinan $\left(\mathrm{X}_{1}\right)$ terhadap prestasi belajar matematika (Y). Adapun besarnya kontribusi pengaruh yang signifikan kedisiplinan terhadap prestasi belajar adalah 20,8\%. 
3. Hipotesis Ketiga yaitu Terdapat Pengaruh Task Commitment terhadap Prestasi Belajar Matematika

Hipotesis tersebut diuji menggunakan uji $\boldsymbol{t}$ dengan kriteria pengujian: terima $\mathrm{H}_{0}$ jika $\boldsymbol{t}_{\text {hitung }}<$ $\boldsymbol{t}_{\text {tabel}}$, dan tolak $\mathrm{H}_{0}$ jika $\boldsymbol{t}_{\text {hitung }}>\boldsymbol{t}_{\text {tabel }}$. Untuk nilai $\boldsymbol{t}_{\text {tabel }}$ ditentukan dari tabel distribusi $\boldsymbol{t}$ untuk $\alpha=0,05$ pada $d k$ $=53$, besarnya nilai $\boldsymbol{t}_{\text {tabel }}=2,006$. Setelah dilakukan perhitungan pada data hasil penelitian, diperoleh nilai $\boldsymbol{t}_{\text {hitung }}=2,053$.

Dengan demikian, ternyata $\boldsymbol{t}_{\text {hitung }}>\boldsymbol{t}_{\text {tabel }}$ yaitu 2,053 $>2,006$, maka $\mathrm{H}_{0}$ ditolak dan terima $\mathrm{H}_{1}$, hal ini dapat diartikan terdapat pengaruh yang signifikan task commitment $\left(\mathrm{X}_{2}\right)$ terhadap prestasi belajar matematika (Y). Adapun besarnya kontribusi pengaruh yang signifikan task commitment terhadap prestasi belajar matematika adalah $16,5 \%$.

\section{Pembahasan Hasil Penelitian}

1. Pengaruh Kedisiplinan dan Task Commitment Secara Bersama-sama terhadap Prestasi Belajar Matematika

Mengacu pada perhitungan data hasil penelitian prestasi belajar matematika $(\mathrm{Y})$, kedisiplinan $\left(\mathrm{X}_{1}\right)$ dan task commitment $\left(\mathrm{X}_{2}\right)$, dapat disimpulkan bahwa kedisiplinan $\left(\mathrm{X}_{1}\right)$ dan task commitment $\left(\mathrm{X}_{2}\right)$ secara bersama-sama berpengaruh signifikan terhadap prestasi belajar matematika (Y). Berdasarkan hasil penelitian ini diketahui bahwa terdapat pengaruh yang signifikan kedisiplinan dan task commitment secara bersama-sama terhadap prestasi belajar matematika sebesar $37,3 \%$. Hasil penelitian ini sejalan dengan pendapat Supardi (2014), bahwa perilaku disiplin muncul karena adanya kesadaran diri sendiri serta dapat muncul karena ada dorongan dari luar untuk mendapatkan prestasi belajar matematika yang maksimal. Hasil penelitian ini juga sesuai dengan penelitian Firmanto (2013), bahwa task commitment berpengaruh signifikan terhadap prestasi belajar. Penelitian tersebut menyatakan bahwa siswa dengan task commitment tinggi memiliki sikap ulet, tekun, percaya diri dan yakin untuk menyelesaikan tugas dengan baik. Hal tersebut akan mempersempit kesenjangan antara potensi yang siswa miliki (intelektual/berbakat) dengan prestasi yang ditunjukkan. Oleh karena itu, kedisiplinan yang dimiliki siswa harus terus ditingkatkan lebih baik lagi dibarengi dengan task commitment pada pelajaran matematika secara bersama-sama agar dapat membangun prestasi belajar matematika menjadi lebih baik.

2. Pengaruh Kedisiplinan terhadap Prestasi Belajar Matematika

Mengacu pada perhitungan data hasil penelitian untuk data prestasi belajar matematika (Y) dan kedisiplinan $\left(\mathrm{X}_{1}\right)$, dapat disimpulkan bahwa kedisiplinan $\left(\mathrm{X}_{1}\right)$ berpengaruh signifikan terhadap prestasi belajar matematika (Y). Berdasarkan hasil penelitian diketahui bahwa prestasi belajar matematika dipengaruhi secara signifikan oleh kedisiplinan sebesar 20,8\%. Hal ini sejalan dengan hasil penelitian Supardi (2014) yang menyatakan bahwa kedisiplinan muncul karena adanya kesadaran diri sendiri serta dapat muncul karena ada dorongan dari luar untuk mendapatkan prestasi belajar matematika yang maksimal. Oleh karena itu, kedisiplinan yang dimiliki siswa pada pelajaran matematika harus terus dibangun secara kontinu dengan lebih baik lagi 
dari waktu ke waktu setiap saat sehingga secara langsung akan dapat meningkatkan prestasi belajar matematika menjadi lebih baik.

Kedisiplinan siswa adalah ketaatan siswa terhadap peratuanperaturan yang berlaku demi terciptanya suatu tujuan. Disiplin sangat diperlukan dalam kegiatan belajar agar dapat membangun dan melatih kepribadian siswa. Unaradjan (2003: 10) menyatakan bahwa, disiplin diri adalah tingkah laku manusia yang dikontrol, terkendali, serta teratur yang berpijak pada kesadaran dan maksud dari pribadi yang bersangkutan agar keberadaannya selalu membahagiakan dirinya dan orang lain. Guru memberi kesempatan bagi siswa untuk berlatih membuat keputusan dan melakukan kontrol diri. Pembinaan dan pendidikan yang diberikan kepada siswa bertujuan agar siswa memiliki sifat disiplin, bertingkah laku sesuai dengan aturan bukan karena paksaan dari pihak lain melainkan dari dalam diri sendiri.

Fungsi disiplin menurut Tu'u (2006: 38) adalah: (1) menata kehidupan bersama; (2) membangun kepribadian; (3) melatih kepribadian; (4) pemaksaan; (5) hukuman; (6) menciptakan lingkungan yang kondusif. Fungsi kedisiplinan ini nyata dapat dirasakan dalam kehidupan sehari-hari. Dalam kegiatan belajar, fungsi ini juga dapat dirasakan siswa, diantaranya ketika siswa disiplin terhadap peraturan dan norma-norma yang berlaku, perilaku ini akan tertanam dalam diri seseorang dan akan menumbuhkan kepribadian yang baik, disiplin bukanlah sebuah perilaku yang dapat terbentuk secara instan, tetapi melalui latihan dalam perilaku kegiatan sehari-hari seperti dalam belajar. Siswa akan disiplin dan penuh tanggungjawab mantaati peraturan sekolah untuk menghindari hukuman yang akan menciptakan lingkungan yang kondusif serta aman dan tentram.

Kedisiplinan senantiasa memaksa siswa untuk mentaati segala peraturan yang ada di sekolah. Kedisiplinan yang harus dibangun adalah segenap perilaku siswa dengan mengacu pada instrumen kedisiplinan berdasarkan penelitian ini. Beberapa perilaku yang dimaksud diantaranya patuh atau taat dalam menepati jadwal belajar, patuh atau taat dalam mengatasi semua godaan yang akan menunda waktu belajar, patuh atau taat terhadap diri sendiri untuk dapat menumbuhkan kemauan dan semangat belajar, patuh atau taat untuk senantiasa menjaga kondisi fisik, serta patuh atau taat terhadap aturan-aturan hukum dan norma yang berlaku.

3. Pengaruh Task Commitment terhadap Prestasi Belajar Matematika

Mengacu pada perhitungan data hasil penelitian untuk variabel prestasi belajar matematika (Y) dan variabel task commitment $\left(\mathrm{X}_{2}\right)$, dapat disimpulkan bahwa task commitment $\left(\mathrm{X}_{2}\right)$ berpengaruh signifikan terhadap prestasi belajar matematika (Y). Berdasarkan hasil penelitian yang sudah dilakukan, diketahui bahwa prestasi belajar matematika dipengaruhi secara signifikan oleh task commitment sebesar 16,5\%. Hal ini sejalan dengan hasil penelitian Firmanto (2013) yang menyatakan bahwa task commitment berpengaruh signifikan terhadap prestasi belajar. Oleh karena itu, task commitment siswa pada pelajaran matematika harus dibangun secara kontinu dengan progres yang lebih baik lagi dari waktu ke waktu. 
Task commitment siswa pada pelajaran matematika menjadikan suatu motivasi untuk dapat menstimulasi semangat dalam belajar matematika, sehingga secara langsung akan dapat meningkatkan prestasi belajar matematika menjadi lebih baik. Definisi komitmen terhadap tugas (task commitment) dikemukakan oleh Sutisna (2010: 268), komitmen terhadap tugas (task commitment) yaitu suatu energi dalam diri seseorang yang mendorong seseorang tersebut untuk tekun dan ulet mengerjakan tugasnya meskipun mengalami macam-macam rintangan dalam meyelesaikan tugas yang menjadi tanggung jawabnya karena individu tersebut telah meningkatkan diri terhadap tugas tersebut atas kehendak sendiri. Task commitment mempunyai hubungan yang erat dengan prestasi belajar matematika, karena task commitment merupakan motivasi dan faktor pemicu dalam diri seseorang yang mendorong orang untuk tekun dan ulet dalam mengerjakan tugas yang sudah menjadi tanggung jawabnya, meskipun menghadapi berbagai macam halangan. Peran guru dalam pembelajaran matematika adalah untuk terus memotivasi siswa agar mempunyai sikap tanggung jawab serta berkomitmen tinggi terhadap semua tugas pada mata pelajaran matematika yang diberikan guru.

Task commitment merupakan motivasi dan faktor pemicu dalam diri seseorang yang mendorong orang untuk tekun dan ulet dalam mengerjakan tugas yang sudah menjadi tanggung jawabnya, meskipun menghadapi berbagai macam halangan. Komitmen ini bukan hanya ucapan janji semata, namun ada tindak lanjut berupa tindakan nyata dalam menyelesaikan tugas. Task commitment siswa pada pelajaran matematika yang harus dibangun adalah segenap perilaku dengan mengacu pada instrumen task commitment siswa berdasarkan penelitian ini. Task commitment siswa pada pelajaran matematika yang dimaksud dalam penelitian ini, secara spesifik adalah tekun menghadapi tugas, ulet, mampu berprestasi sendiri, ingin mendalami bidang pengetahuan yang diberikan di kelas, selalu berusaha untuk berprestasi sebaik mungkin, menunjukkan minat terhadap beragam masalah disaat mengikuti mata pelajaran matematika, senang dan rajin belajar dengan penuh semangat dan antusias tinggi, tidak cepat bosan dengan tugas-tugas rutin, dapat mempertahankan pendapatnya, serta menunda pemuasan kebutuhan sesaat untuk mencapai tujuan di kemudian hari.

\section{SIMPULAN DAN SARAN}

\section{Simpulan}

Berdasarkan penelitian dan perhitungan hasil penelitian yang sudah dilaksanakan, diperoleh simpulan hasil penelitian terdapat pengaruh yang signifikan kedisiplinan dan task commitment secara bersama-sama terhadap prestasi belajar matematika pada siswa di SMP PGRI Plumbon, Kabupaten Cirebon. Besarnya kontribusi pengaruh yaitu sebesar $37,3 \%$; terdapat pengaruh yang signifikan kedisiplinan terhadap prestasi belajar matematika di SMP PGRI Plumbon Kabupaten Cirebon, yaitu sebesar 20,8\%; dan terdapat pengaruh yang signifikan task commitment terhadap prestasi belajar matematika di SMP PGRI Plumbon Kabupaten Cirebon, yaitu sebesar 16,5\%. 


\section{Saran}

Berdasarkan hasil penelitian yang sudah dilaksanakan, peneliti berharap sistem pendidikan di Indonesia dapat terus berkembang menjadi lebih baik. Peneliti juga berharap agar dari pihak guru dan sekolah untuk hasil penelitian ini dapat digunakan sebaik mungkin dalam upaya meningkatkan prestasi belajar matematika siswa. Adapun saran peneliti antara lain bagi peneliti lanjutan yaitu mengingat keterbatasan peneliti, penelitian ini hanya dilakukan pada siswa kelas VIII di SMP PGRI Plumbon Kabupaten Cirebon tahun ajaran 2015/2016, sehingga generalisasi hanya berlaku bagi subjek yang memiliki karakteristik yang sama dengan subjek pada penelitian ini.

Bagi siswa, hendaknya meningkatkan kedisiplinan dan task commitment khususnya pada mata pelajaran matematika. Dengan begitu siswa memungkinkan dapat meraih prestasi belajar matematika yang maksimal. Bagi sekolah, diharapkan dapat membuat peraturan tegas berkaitan dengan perilaku disiplin dan task commitment siswa secara mengikat yang disertai dengan sanksi bagi yang melanggar, sehingga dengan adanya sanksi diharapkan siswa dapat mengikuti dan mematuhi serta melaksanakan aturan tersebut dengan sungguh-sungguh. Bagi guru, hendaknya dapat memberikan kesadaran untuk siswa akan pentingnya sikap disiplin dalam belajar dan task commitment agar siswa tidak melalaikan tanggung jawabnya. Guru juga diharapkan dapat memberikan motivasi sekaligus memberi contoh teladan kepada siswa untuk dapat bersikap disiplin dan tanggung jawab terhadap tugas. Bagi orangtua, hendaknya sebagai sosok figur sentral hidup siswa di lingkungan pendidikan informal mampu membangun kehidupan pribadi dan kehidupan keluarga yang utuh, sehingga bisa membangun sikap disiplin dalam belajar dan task commitment dalam keluarga.

\section{DAFTAR RUJUKAN}

Akbar, R. dan Hawadi. 2005. Identifikasi Keberbakatan Intelektual Melalui Metode Non-Tes. Jakarta: Grasindo.

Arikunto, S. 2006. Prosedur Penelitian Suatu Pendekatan Praktik. Jakarta: Rineka Cipta.

Djiwandono, S. 2002. Psikologi Pendidikan. Jakarta: Grasindo.

Firmanto. A. 2013. Kecerdasan, Kreativitas, Task Commitment dan Jenis Kelamin sebagai Prediktor Prestasi Hasil Belajar Siswa. http://www.e-jurnal.com/2013/ 09/kecerdasan-kreativitas-task-commitment.html? $\mathrm{m}=1$. (Diakses tanggal 24 Maret 2016).

Jakaria, J. 2014. Cara Menentukan Luas Juring, Tembereng dan Panjang Busur. http://zha-karya.blogspot.co.id/2014/01/materi-matematika-kelas-8-smpmts-bab6. $\mathrm{html} ? \mathrm{~m}=1$. (Diakses tanggal 26 Februari 2016).

Prijodarminto, S. 2004. Disiplin Kiat Menuju Sukses. Jakarta: Pradja Paramita.

Riduwan. 2006. Belajar Mudah Penelitian untuk Guru, Karyawan dan Peneliti Pemula. Bandung: Alfabeta.

Slameto. 2010. Belajar dan Faktor-faktor yang Memengaruhinya. Jakarta: Rineka Cipta.

Supardi, U. S. 2012. Aplikasi Statistika dalam Penelitian. Jakarta: Ufuk Publishing. 
Supardi, U. S. 2014. Peran Kedisiplinan Belajar dan Kecerdasan Matematis Logis dalam Pembelajaran Matematika. Jurnal Formatif Unindra. 4(2): 80-88.

Sutisna, S. 2010. Perbedaan Kecemasan dalam Menghadapi Ujian antar Siswa Program Reguler dengan Siswa Program Akselerasi. Karya Ilmiah (tidak diterbitkan) Medan: Fakultas Psikologi Universitas Sumatera Utara. http://repository.usu.ac.id/bitstream/123456789/3650/1/10E00545.pdf. (Diakses 1 April 2016).

Tu'u, T. 2006. Peran Disiplin pada Perilaku dan Prestasi Siswa. Jakarta: Grasindo. Unaradjan, D. 2003. Manajemen Disiplin. Jakarta: Grasindo. 